\title{
Contextualizing Aesthetics as Social Engagement for Teacher Education
}

\author{
Adam I. Attwood, $\mathrm{PhD}$ \\ Austin Peay State University, Clarksville, Tennessee, United States \\ (iD) https://orcid.org/0000-0002-4718-9272
}

Contact: attwooda@apsu.edu

\section{Abstract}

Aesthetics is a type of literacy; however, it has been missing in generalist meta-analyses of teacher education. This article adds to the literature by synthesizing aesthetics theory, especially for implications of the historical development of ideas related to visual arts and aesthetics broadly defined for inclusive teacher preparation that promotes social engagement. Various viewpoints are explored in this article for contextualizing the field of aesthetics education as it relates to the preparation of generalist $\mathrm{K}-12$ teachers who are not training to be fine arts teachers. With context, generalist $\mathrm{K}-12$ teachers can be equipped to integrate the arts across other content areas.

Keywords: aesthetics; social engagement; teacher education; generalist; art; $K-12$ education

Date Submitted: October 26, 2019 | Date Published: February 18, 2020

\section{Recommended Citation}

Attwood, A. I. (2020). Contextualizing aesthetics as social engagement for teacher education. Journal of Social Change, 12, 19-31. https://doi.org/10.5590/JOSC.2020.12.1.03

\section{Introduction}

Aesthetics has been called a type of literacy that intertwines psychology and art history to make "style an important educational topic" (Parsons, 1990, p. 145) for conceptual and experimental studies. It was, however, missing in a prominent generalist meta-analysis of teacher education studies (Avalos, 2011). This article adds to the literature by synthesizing aesthetics education theory, especially for implications of the historical development of ideas related to visual arts-and aesthetics broadly conceived-for inclusive teacher education. As such, this adds to Yob's (2018) discussion of what a conceptual framework for a social change curriculum can be. Literature from various viewpoints is explored in this article for contextualizing the field of aesthetics education as it relates to the preparation of generalist $\mathrm{K}-12$ teachers who are not training to be fine arts teachers. With context, generalist $\mathrm{K}-12$ teachers can be equipped to integrate the arts across other content areas, promoting social change.

\section{Theoretical Framework}

Aesthetics, when operationalized as a tool for education, fosters the individual imagination to move toward enacting a change. Drawing from Sameshima and Sinner's (2009) approach to aesthetic inquiry, this 
conceptual evaluation of aesthetics education establishes context for what aesthetics can mean for teacher education. This conceptual evaluation is situated within Greene's (2001) framework of aesthetic education in which it encourages "learners to notice what is there to be noticed, and to lend works of art their lives in such a way that they can achieve them as variously meaningful" (p. 6). As such, this discussion is both historical for context and generative toward a recommendation that starts a conversation for integrating applied aesthetics for teacher educators. It is applicable to the preparation of preservice teachers for the general classroom to integrate the arts as aesthetic inquiry across the $\mathrm{K}-12$ subjects.

\section{Historical Context of Aesthetics in Education}

Aesthetics can be a form of social change through engagement of creativity, because its applied form-such as in an arts-integration unit or course-promotes an individual's investment in their own creativity as it can be applied to various subjects they may teach. The field of "experimental aesthetics" emerged in the late 2oth century, predominantly under the direction of Berlyne (1974) and ostensibly influenced by the founding of Glaser and Strauss's (1967/2012) grounded theory approach. Berlyne's (1974) experimental aesthetics was originally an empirically based or quasi-experimental form of inquiry through art theory that drew on the disciplines of art history and philosophy. Following Parsons (1990), one of the studies that set the stylistic tone for experimental aesthetics in general education research was conducted by Lauren Sue Seifert (1992), who concluded,

Even naive observers who had had no formal courses in art or art history displayed aesthetic sensitivities to differences in works of art. Furthermore, they felt comfortable making judgments about the relative aesthetic values of paintings, and they freely expressed the reasons for those judgments. (p. 77)

Seifert's (1992) assertion can be interpreted as forming part of the foundation for how arts-integration was later conceptualized for generalist K-8 teachers. Nevertheless, there was still a gap in addressing preservice teachers' perceptions, understandings, and self-efficacy of aesthetics in education. This is particularly important because preservice teachers will influence children's perceptions of their self-efficacy. Five years after Seifert's study, Jalongo and Stamp's (1997) textbook for preservice K-8 teachers was published in which aesthetics as artmaking-across-the-curriculum was championed for all $\mathrm{K}-8$ teachers to use the arts as a teaching tool in multiple subjects. This established a precedent in aesthetics education for $\mathrm{K}-8$ teacher preparation programs to include an arts-integration course.

Maxine Greene's (2001) work expanded the field of aesthetics education as both art inquiry and philosophical inquiry. Mary Weems (2003) explored what she called the "imagination-intellect" to critically examine institutions for fostering self-efficacy. The imagination and the intellect were necessarily intertwined, according to Weems, because the imagination allows for people to envision possibilities different than the current state, and the intellect allows for people to apply that imagination to a shared reality to affect change. Crouch (2006) highlighted music, especially jazz, in the context of reaching multiple audiences. Frawley (2013) suggested that preservice teachers should have aesthetics education as part of their teacher preparation program. Such a course was envisioned, Frawley noted, for the purpose of generalist K-8 teachers becoming creators of aesthetic content. This art-production approach would be more exploratory than hierarchical with the intent of fostering student-centered creativity that would lead to self-efficacy for integrating arts-based approaches to teaching and learning in mathematics, science, social studies, and literacy. This, as discussed by Jalongo and Stamp (1997), can increase the likelihood of in-service teachers fostering and celebrating their students' aesthetic learning through aesthetic content production in schools for and with multiple subjects. When teachers are encouraged to create curriculum with their teacher education instructors, they will be better equipped to coconstruct a student-centered learning environment in 
elementary school. To do so, creativity should be fostered through arts-integrated assignments that encourage students to interact with social studies through poetry, music, and dance or mathematics and science through the integration of the visual arts. Drawing diagrams is one part of this process, but students should be encouraged through project options that require some form of aesthetic process selected by the student based on options that are developmentally scaffolded by grade level.

Sameshima and Sinner (2009) suggested aesthetics-based inquiry to address preservice teachers' understandings through "dialogic inquiry" in which the allegory of soma heliakon (Greek for "the solar body of the sun") was used as part of their application of the parallaxic praxis research model (Sameshima \& Vandermause, 2008). The use of metaphor and allegory advances deeper understandings through creative communication and content creation. Sameshima and Sinner (2009) specifically addressed this through the "interconnected artful expressions of a poem" (p. 272) that were developed from "our e-letters, coding and collecting salient phrases and aspects that continued to resonate in relation to teacher education” (p. 272).

The individual teacher may not be aware of or know how to develop and use their aesthetic, so Frawley (2013) emphasized that coursework in aesthetics should be part of teacher education. At first, aesthetics may seem like an abstraction, but when aesthetics education is taught with a view toward a product, such as a curriculum unit or art piece that is used to teach another subject, then its abstraction is grounded in a shared reality. There are some studies on the concept of aesthetic theory and hermeneutical context in school using qualitative and mixed-methods inquiry (see Burton et al., 1999; Oreck, 2004; Shockley et al., 2008; Wiebe et al., 2007, for conceptual, qualitative methods; see Smithrim \& Upitis, 2005, for a mixed-methods approach). Greene's (2001) definition of aesthetics education seemed to become the working definition in relation to teaching and learning in school:

"Aesthetic education," then, is an intentional undertaking designed to nurture appreciative, reflective, cultural, participatory engagements with the arts by enabling learners to notice what is there to be noticed, and to lend works of art their lives in such a way that they can achieve them as variously meaningful. (p. 6)

Frawley (2013) further suggested that "interactive production of knowledge is the hallmark of aesthetic education" (p. 23). The potential power of aesthetic theory for teacher preparation may further emerge in context with the work of Sameshima and Sinner (2009), who suggested a type of aesthetic practice for teacher-researchers in which analysis of student work can be done through artistic representations that emanated from learning more about the self, or soma heliakon. That is, the intentional aesthetic promotes learning to transcend rote memorization and becomes an interactive process of intrinsic motivation to adapt, which tends to increase proactive learning and application of learning. This practice has implications in that theoretical reification of the teacher identity is influenced by various strands-historical, contemporary, and the combination of the two for a reimagined identity aesthetic, or what P. B. Joseph et al. (2011) called the process of "reculturing" (p. 55).

Garber (1992) explained the importance of feminist aesthetics to the discussion of aesthetics education, adding an expanded view of what reculturing means in the 21st century. Implicated in this view is the notion that teacher education should acknowledge individual difference within the groups represented in preservice teacher training programs. Feminist aesthetics is more than a conceptual discussion; it is a lived experience (Garber, 1992). Likewise, hip-hop has been theorized as an aesthetic for understanding an historically marginalized group, encouraging self-advocacy, and fostering self-efficacy in their schools (Clemons et al., 2017; Petchauer, 2012).

Whether the tool is dance, visual art, music, or a combination, aesthetics is a common denominator that all students can interface with through what Weems (2003) called the imagination-intellect. That imaginationintellect is essential for advancing social change in schools. Weems, according to Negishi and Elder (2005), 
"sees the school as an important agent that can produce activists to challenge social problems, in particular, those surrounding issues of race and ethnicity” (p. 473). Likewise, P. B. Joseph et al.'s (2011) conceptual process-reculturing-suggests that the development of an aesthetically responsive curriculum tends to evoke the need for an intrinsic reculturing-or an intentional, inclusive policy framework-for preservice teachers as they develop into teachers.

If a student feels left out of the dialogue, they may not exploring the subject further. Being included in dialogue can increase self-efficacy. Aesthetics is a part of dialogue, which itself is a component of a literacy framework for social engagement, whether overtly acknowledged or not (Weems, 2003). For example, in the study of history and social studies, Whitaker (2015) noted that his personal interest in medieval European history was at the intersection of what became a critical dialogue surrounding race as a cultural construct between the past and present context. Whitaker asserted that "the Middle Ages have been thoroughly raced. The question at hand is, exactly how are they raced?" (p. 7). The implication of Whitaker's discussion applies to the question of how social engagement is affected by the way cultural constructs are taught across time and place within a general community outside of school as well as within it. Aesthetics is a part of that dialogue in that social studies topics are imbued with aesthetic understandings and assumptions of the portrayal of people and events within cultural, psychological, and physical settings that also include the performing arts, fine arts, and decorative arts. To better understand, challenge, or reinforce an historical narrative would seem to require aesthetic components or an analysis of the aesthetics of that topic and, just as importantly, cultivate students' imagination to interface with the given topic, place, and time. This personal investment in learning about something seemingly distant or disconnected from the individual in the present would seem to require a creative approach to generate intrinsic interest and understanding. Aesthetic products affect all of this-from movies to visual art and performing arts. What Weems (2003) called the imagination-intellect is essentially a component of aesthetic education in which personal connection is developed through aesthetic activities whether arts-based, arts-informed, or arts-integrated. Preservice teachers can learn more about the potential benefits of aesthetic inquiry through practicing the examination of the art through time, the way people talked about each other's clothing style, appearance, voice, music, and examination of material culture.

Social change can-and in some ways must-emanate from individual and group understandings of aesthetics. This is often subconscious, but it does not always have to be, as that is what a curriculum rooted in aesthetic approaches to teaching and learning can do. Aesthetics-based education can promote what Weems (2003) called the imagination-intellect or what Sameshima and Sinner (2009) called moving toward soma heliakon. Aesthetics can reinforce the status quo or change it. Aesthetics, then, is taking the way the senses interpret the visual, audio, and other senses that are seen as desirable or not desirable and channeling them toward a goal. This can have some of the greatest potential to affect change. Poe et al. (2019) noted, "Music is a unique medium for the praxis of ideology" (p. 36). Music, in other words, can be a catalyst for social change and, perhaps more meaningful for the individual, can give a sense of self-efficacy to imagine possibilities toward which to strive. A movie, for example, can change someone's opinion. A movie is an aesthetic product that generally combines the audiovisual with music to reinforce a message, a story, a possibility. Sometimes the viewer will interface not just because of the words themselves but because of the combined aesthetic message. A lesson that includes comparison of poems and student's own reinterpretation of poems to write their own is an example of an aesthetic curriculum. It can lead to social change or social reinforcement. Accomplishing change requires an aesthetics-based curriculum in $\mathrm{K}-12$, which in turn leads to the importance of aesthetics education in educator preparation programs.

\section{Aesthetics for Preservice Teachers to Explore}

To teach arts-integration is not to teach fine art; it is to teach creativity. As such, aesthetics as social change is a potential next step to what Yob (2018) called the promotion of "the common good" (p. 71), especially for 
K-12 teacher education. Jalongo and Stamp (1997)-in what was a precedent-setting textbook on aesthetic education focused on early childhood education-championed the notion that teachers who are not arts professionals can and should foster aesthetics in the classroom through arts-integration across the curriculum. They said,

Mr. Brody, a student teacher, is a good example ... By sharing his enthusiasm for art with the children (rather than by being a professional artist himself) Mr. Brody has contributed to children's aesthetic education. With each of the activities listed, he watched children's interest in modeling and sculpting renew and expand. (p. 17, parenthetical in original)

Gelineau (2012) similarly asserted, “a teacher need not be an artist, musician, dancer, or other arts professional in order to provide a nurturing arts climate that will vitalize the learning process" (p. 12). In other words, a teacher can teach through the arts without being a professional artist or professional art teacher. Seifert's (1992) study in experimental aesthetics suggested that students without prior training could analyze art. Teacher-educators can go beyond this to encourage preservice teachers to learn through the an artsintegration course that combines constructivist approaches to teaching and learning to foster aesthetic development in students (Barry, 1996).

When students create content, they are more likely to be invested in the learning process. This can be particularly powerful for learning when combined with the teacher's oversight in guiding students' creative process (Berlyne, 1974; Jalongo \& Stamp, 1997). If the professor of the arts-integration course is successful, the preservice teachers will have a new or renewed confidence in their own process of art-making that leads to continued production of aesthetic curriculum products.

Jalongo and Stamp (1997) asserted that creativity is an aesthetic process that can be learner-centered and, when creativity is fostered by the teacher, the creativity is learner-directed. Some of the benefits of aesthetics education may be seen in early childhood education through all grade levels. Aesthetic education uses multiple senses, arts, style, and design so that early learning can be as much child-directed as it is teacherdirected because, according to Jalongo and Stamp,

Child-directed means that the child monitors his or her own progress and does not need excessive adult intervention to complete the desired task. In order for children to initiate and direct arts activities, classrooms must create conditions for learning in the arts. (p. 15)

The same could also be said for preservice teachers during their coursework. It is in the fostering of creativity that $\mathrm{K}-8$ students and preservice teachers may apply creativity across subjects. The generalist $\mathrm{K}-8$ teacher is expected to teach multiple subjects and should have confidence in their creativity-and their style-to foster learning and innovation across multiple subjects through the arts. Sometimes that means protection of identity as much as it does the growing of a new aspect of expressed identity.

\section{Aesthetic Perception}

A sample of recent research suggested that a systematic analysis of teacher-identity formation and selfreflective perception is important in K-12 systems (Cheng et al., 2009; Coldron \& Smith, 1999; Geijsel \& Meijers, 2005; Hall, 2010; Hong, 2010; D. Joseph \& Heading, 2010; Robinson \& Timperley, 2007; Shockley et al., 2008; Thomas \& Beauchamp, 2011; Weems, 2003). Style as aesthetic perception is part of teacher identity. Throughout the literature on aesthetics, the notion of style as individual personality emerged, because style affects perception. 
Garrison (1995) agreed with Alfred Whitehead's (1929/1967) emphasis on the importance of a teacher's individual style, because personal style is a factor affecting the learning environment. "For Whitehead," Garrison (1995) noted, "style was as much an intellectual and aesthetic as it was a moral virtue" (p. 41). Garrison further stated that "individual style should be among the most important aims of teacher preparation" (p. 41, emphasis in original). The teacher is, in effect, on a curricular fashion runway in which the options tend to be adaptation to the du jour curriculum standards, or proactively responding to their current students in ways that evoke the reverence of school ritual. As Rud and Garrison (2010) noted, "Reverent teachers ... understand the importance of ritual and ceremony in establishing classroom and school community" (p. 2780). The curricular fashion runway is a ritual of school in which teachers' aesthetics are posed and on display in ways that can inspire students. If teachers are aware of their own aesthetic and able to unlock and channel it for responding to the classroom environment, they can foster aesthetic innovation. The teacher's style is on display and under evaluation by students every class session, which is why it is important to understand and control classroom ritual.

Augmenting the aesthetic should inspire students in evaluating their own aesthetic, developing awareness of it, and practicing ways to create through learning about and channeling their aesthetic skills. With this statement forming the assumption of the author's theoretical lens of teacher preparation, it may be stated that exploring teacher identity is important for understanding aesthetics as one of the variables for student success as well as teacher retention in the profession.

Dewey's (1934/2005) concept of the teacher's style seemed to be a distinct psychological construct that should be intentionally and thematically fostered in teacher education programs. For Dewey, the arts were a vast horizon in which everyone was a denizen of the arts, because audiovisual representations are the world. Marsh (2004) stated, "By defining art as experience, Dewey also sought to dissolve the binary structures of aesthetic rifts" (p. 91) so that all students could see themselves as artistic. Similarly, Nel Noddings (2012) stated, "Dewey insisted that teaching should induce learning, but he did not mean that it should cause every student to learn some piece of information or skill predetermined by the teacher" (p. 50). Aesthetics has perhaps some of the greatest potential in fostering learning that is not predetermined; therefore, there is very likely a longlasting benefit to teacher practice in an aesthetics-based course (Frawley, 2013). Establishing an aesthetically responsive curriculum is of key importance for advancing inclusion (Furniss, 2008; Lynch, 2007).

The aesthetic is personal and yet part of the public persona. Bayles and Orland (2001) contended, "Nowhere is feedback so absolute as in the making of art" (p. 49). That which is of the aesthetic-whether fine art, decorative art, arts-informed curriculum, or indeed anything visual and tangible that an individual can interact with-does not exist in the vacuum of the individual mind, but instead affects others who interact with the aesthetic that the given individual represents in others' perception. Goffman (1959) suggested that this was a "performance" of the self in the public forum. The aesthetic identity, then, is visual representation as well as the performance of perception. This can be from emotions as much as from rationality from the vantage point of the self, of the observer, and of the individuals who interact with each other. It is with this understanding of the aesthetic spectrum that Bayles and Orland (2001) suggested the potential perils and rewards of artmaking, because the aesthetic identity is both visual art and performance art personified through the teacher character in which the emotional and the rational are in tension. This tension goes to the heart of the potential perils and rewards of transforming or what P. B. Joseph et al. (2011) called "reculturing" the teacher identity from one context, such as the general $\mathrm{K}-8$ classroom, to another context, such as the museum or public theatre stage (Dudley, 2010; Geijsel \& Meijers, 2005; Hall, 2010; D. Joseph \& Heading, 2010; Oreck, 2004).

Children's literature influenced the nexus between past and present that likely influenced creative cultural syncretism, because people tend to carry forward into adulthood their childhood understandings of the past (Lehr, 2001). Kelley and colleagues (2013) suggested that visual art in children's literature is laden with 
values, and it is the visual medium that communicates those values when combined with textual reinforcement. The phenomena of children's literature that romanticizes historical constructs is another point of contention, as Bernadette Baker (2013) asked of the purposes of history in 21st-century society. If modern individuals "transition between two different conceptions of reality that redefine what a society is" (p. 43), then aesthetics may be the transformative praxis of reenvisioning school in society.

Bayles and Orland (2001) asserted, "Art is often made in abandonment, emerging unbidden in moments of selfless rapport with the materials and ideas we care about" (p. 37). Art is not necessarily made in abandonment-quite the contrary for some. But perhaps most art is indeed an extension of the ideas that an individual or group cares about. Artistry and the paths that lead to becoming an artist are many, varied, and often personal in that artists produce pieces that may be extensions of themselves. The artful creation is of the "materials and ideas we care about" (p. 37). Similarly, the noted representational painter Robert Henri (1923/2007) suggested in his book The Art Spirit that everyone has the arts within them; however, he claimed that "Few have the courage and stamina to see it through" (p. 12). Becoming acquainted with the self can be a lonely road that can benefit others, but at a cost to the self.

Henri (1923/2007) believed, "You have to make up your mind to be alone in many ways" (p. 12). This suggests the potential importance of personality case studies of artists, because aethetic inquiry can focus on what motivates individuals. There is no one correct way to be an artist. There are many ways to be a "correct" artist. As Henri stated, "All the past can help you" (p. 12). Here again is another link to understanding history, especially as a necessary contextual tool for teacher education curriculum. For an artsy individual to better know the self and, thus, teach students through a self-aware lens, the artist should be comfortable with apparent paradox of style in which the style may seem objectively like a shared reality and yet may be perceived differently depending on vantage point-or, as Gadamer (1975/2013) suggested, the "horizons" of personal and shared cultural knowledge (see also Costantino, 2013). Every artist is correct to somebody. Perception depends on context to discern how each part of a thing (e.g. a representational painting) goes together to form a cohesive whole that represents ideas that are part of culture and just about everything thought of in the mind.

Bayles and Orland (2001) noted the "perils and rewards" of artmaking, proposing that "The irony here is that the piece you make is always one step removed from what you imagined" (p. 16). This suggested a deficit model as being a default for students. However, teachers are more likely to foster students' creativity when they transcend the deficit model and instead celebrate individual creativity-especially in early childhood education (Jalongo \& Stamp, 1997). What is learned in early childhood tends to multiply into adulthood and become engrained in the psyche, which is part of the reason why Tyson Lewis (2014) asserted,

we must pay careful attention to passion in education, not in order to reduce education to the alteration of the passions but rather in order to understand how education exists in the moment of an uncertain community poised between passion and logos-that is the space necessary to verify what I refer to as the "theatrical will." (p. 17)

This concept adds to Goffman's (1959) idea about everyday presentation, except that Lewis (2014) echoed the notion that "education begins with a rupture of the partitioning of the sensible, the transcendental dimensions of space and time that form the basis of imaginative constructions" (p. 17). As both authors suggested, individuals perform values through aesthetics.

Shockley et al. (2008) claimed that "If teachers teach who they are, then their hidden inner curriculum directly influences the students they teach" (p. 183). This is part of the concept to which all aesthetic viewpoints seem to adhere. Hong (2010) posited that each teacher's sense of self is rarely static, because "teacher identity is in the process of being shaped by past experience and current circumstances" (p. 1535). Both Hong and Cheng et al. (2009) emphasized the importance of teacher education programs in helping 
preservice teachers to specifically not have expectations that are too idealistic. Yet, there perhaps seems to be a need for idealism to sustain individual passion for teaching. Idealism has an important role in aesthetic education, because it is about advancing ways of being through imagination as much as it is a potentially systematic process (Jalongo \& Stamp, 1997).

Aesthetics can be used to foster innovation in a system subject to continuous reform. Ingersoll and Strong (2011) noted that "teacher induction is distinct from both preservice and in-service teacher professional development programs" (p. 203), because induction is between the phases of student-teacher and contracted professional. This underscores the gap in the literature on aesthetic identity development in teacher education programs in the United States. Rud (2011) discussed historical and philosophical complexities of educational reform, noting,

Educational models of change interact with each other, from top-down mandates of national accountability and assessment standards such as the No Child Left Behind act in the United States, to local innovations proposed by a few teachers to meet a specific need. (p. 132)

When considering that implied question, effectiveness may be linked to self-efficacy in teaching across subjects with arts-integration, especially with the new interest in the concept of aesthetic training outlined by Frawley (2013).

Likewise, the concept of imagination is linked to aesthetic education. Greene (2001) stated that imagination is "at the heart of aesthetic experience" (p. 65) and that imagination is an integral part of aesthetic education in "giving rise on all sides to suggestions that it be central in education and scholarship" (p. 65). Establishing an aesthetically responsive curriculum in teacher induction will help foster confidence in preservice teachers to design aesthetically consistent lessons and a classroom environment that are in harmony with state standards and Common Core curriculum (see A. Joseph, 2011). Blumenfeld-Jones (2012) explained, "The term aesthetics derives from the Greek and means 'sense perception or sensation.' Immediately it is clear that we all have sense perception and sensations” (p. 43, italics in original). Through arts-integration, teachers may more effectively develop their own aesthetic styles through a greater awareness of perception so that they are responsive to their students' aesthetic styles. Part of aesthetic responsiveness in teacher education curriculum and in $\mathrm{K}-8$ curriculum is to encourage the individual and group through creativity by beginning with artistic processes in lessons-what Rex and Woywod (2014) called "vernacular" art. It is vernacular art that forms a part of the foundation for material culture in which preservice K-8 teachers can immediately see themselves as members of creative education who can make art and integrate that art across the curriculum.

Aesthetically responsive curricula are rarely static and, as such, may be understood here as using emergent standards. Schwartz and Copeland (2010) suggested that the "creative-aesthetic" (p. 47) is an essential component of "emergent" curriculum and, as such, it sometimes is in tension with the established structure of school. Eisner (2002) noted, "Indeed, the arts provide a kind of permission to pursue qualitative experience in a particularly focused way and to engage in the constructive exploration of what the imaginative process may engender" (p. 4). Preservice teachers should have a model of aesthetically responsive education in their teacher induction programs so that they have a space within which to explore the imagination for designing curriculum products that promote learning through aesthetics. The teacher is the authoritative guide to validate their products (Ornstein et al., 2011). Hong (2010) contended, therefore, that teacher education programs should systematically include "the practicality of teaching" that "increases awareness of the significance of emotions and prompts preservice teachers to reflect on their own professional identity formation" (p. 1540). In this way, teachers know their core teacher identity intrinsically and may then better adapt to their environment. Aesthetics education should be included in this process.

Henri (1923/2007) suggested that perhaps everyone has an aesthetic, but few explore it because it has rarely been encouraged in the general $\mathrm{K}-12$ school. After that conditioning, the painter noted that it is subsequently 
perhaps not surprising that "Few have the courage and stamina to see it through" (p. 12) after school. Teacher education programs should require an arts-integration course in which all students are encouraged to explore the aesthetic through various media and create arts-based products in the classroom. In this way, the classroom becomes a place of validation for exploring the arts in relation to the multiple subjects.

\section{Recommendations}

Educator preparation programs can include aesthetics as part of one or more courses even if there is not a required arts-integration course. When teachers are encouraged to create and coconstruct learning with their instructors, they will be better equipped to coconstruct a student-centered learning environment in elementary school. For example, a lesson plan assignment in an English language arts and social studies methods course could be focused on how to teach 19th-century poetry through a 21st-century lens. Students can bring their voice to the historical poems by reinterpreting them using modern song lyrics, for example. Students could be assigned an aesthetics assignment in which they design a picture book or instructional sheet to teach a topic in their content area that includes drawing, music, performance art, or similar artsintegrated component.

For example, for a middle school English language arts assignment, a teacher could take the vocabulary list students are assigned for that month and have students design a picture book in which students have to use each of the vocabulary words within an original poem that they write and then illustrate the poem in the picture book. With this aesthetic assignment, students are engaging with the vocabulary for the English language arts unit as well as using their own interests to make sense of the new vocabulary through using the words in a poem and illustrating the poem. This type of aesthetics-informed lesson can be aligned to edTPA standards and, by extension, to the standards of the Council for the Accreditation of Educator Preparation. Aesthetic educational practice can align directly with edTPA Task 2 (Instructing and Engaging Students in Learning), and it also can specifically align with Rubrics 7 (Engaging Students) and 8 (Deepening Student Learning; see Stanford Center for Assessment, Learning, and Equity, 2019). Aesthetic education engages students and deepens learning, because aesthetics combines the senses and encourages students to bring their own stories, community assets, and perspective to a given topic or task. This fosters self-efficacy because of a parallel goal in aesthetic education, as envisioned here, to link the external to intrinsic motivations.

As Weems (2003) suggested, learning can generate change when a traditional narrative is reinterpreted. Use modern song lyrics and have students reinterpret those lyrics to an historical figure's story. Reinterpret a poem to find changes and continuities throughout time. Aesthetics can seem nebulous at first, and yet, it imbues much of an individual's curriculum framework. Aesthetics education for the 21st century may not take the form of a textbook but, instead, it is likely a series of assignments that use the arts as a tool to assist in the teaching of multiple subjects. When students are asked to design their own song to tell a story or take extant songs and reinterpret them for the present, or any number of other arts-informed approaches, they are using aesthetics as applied inquiry that generates self-efficacy. In aesthetics-informed general education, students are using their own creativity to make sense of something that may at first seem out of context to their life. Preservice teachers also would benefit from practicing this approach so that they are more comfortable with aesthetics-based education.

\section{Conclusion}

Aesthetics should be part of teacher education as part of the study of identity formation or induction. Shockley et al. (2008) inferred the ostensible consensus among education researchers: Teacher education programs should challenge preservice teachers to "investigate ... their own hidden inner curriculum" (p. 185). This can give preservice teachers the mindset they need to maintain identity stability when they are in-service teachers 
to have self-efficacy with curriculum. Ultimately, aesthetics education can be a way of broadly supporting inclusion of identities in teacher education from the students' perspectives as much as the teachers' perspectives. Aesthetics education fosters dialogue between students and the content area subject by fostering creativity and, in doing so, encourages a sense of self-efficacy through intrinsic motivation.

\section{References}

Avalos, B. (2011). Teacher professional development in Teaching and Teacher Education over ten years. Teaching and Teacher Education, 27(1), 10-20. https://doi.org/10.1016/j.tate.2010.08.007

Baker, B. M. (2013). The purposes of history? Curriculum studies, invisible objects and twenty-first century societies. Journal of Curriculum Theorizing, 29(1), 25-47.

Barry, D. (1996). Artful inquiry: A symbolic constructivist approach to social science research. Qualitative Inquiry, 2(4), 411-438. https://doi.org/10.1177/107780049600200403

Bayles, D., \& Orland, T. (2001). Art and fear: Observations on the perils (and rewards) of artmaking. The Image Continuum.

Berlyne, D. E. (Ed.). (1974). Studies in the new experimental aesthetics: Steps toward an objective psychology of aesthetic appreciation. John Wiley.

Blumenfeld-Jones, D. S. (2012). Curriculum and the aesthetic life: Hermeneutics, body, democracy, and ethics in curriculum theory and practice. Peter Lang.

Burton, J., Horowitz, R., \& Abeles, H. (1999). Learning in and through the arts: Curriculum implications. In E. Fiske (Ed.), Champions of change: The impact of the arts on learning (pp. 35-46). The Arts Education Partnership and the President's Committee on the Arts and the Humanities. http://artsedge.kennedy-center.org/champions/pdfs/ChampsReport.pdf

Cheng, M. M. H., Chan, K.-W., Tang, S. Y. F., \& Cheng, A. Y. N. (2009). Preservice teacher education students' epistemological beliefs and their conceptions of teaching. Teaching and Teacher Education, 25(2), 319-327. https://doi.org/10.1016/j.tate.2008.09.018

Clemons, K. M., Price, P. G., \& Clemons, K. A. (2017). "Hold up, wait a minute, let me put some freedom in it": Hip-hop based education and the Freedom School experience. In W. Pink \& G. Noblit (Eds.), Second international handbook of urban education (pp. 853-873). Springer; https://doi.org/10.1007/978-3$319-40317-5-45$

Coldron, J., \& Smith, R. (1999). Active location in teachers' construction of their professional identities. Journal of Curriculum Studies, 31(6), 711-726.

https://doi.org/10.1080/002202799182954

Costantino, T. (2013). Cultivating the social imagination of preservice teachers through aesthetic reflection. In B. White \& T. Costantino (Eds.), Aesthetics, empathy and education (pp. 205-220). Peter Lang.

Crouch, S. (2006). Considering genius: Writings on jazz. Cambridge, MA: Basic Civitas Books.

Dewey, J. (2005). Art as experience. Perigee Books. (Original work published 1934)

Dudley, S. (Ed.). (2010). Museum materialities: Objects, engagements, and interpretations. Routledge.

Eisner, E. W. (2002). The arts and the creation of mind. Yale University Press.

Frawley, T. J. (2013). Aesthetic education: Its place in teacher training. Art Education, 66(3), 22-28. https://doi.org/10.1080/00043125.2013.11519220

Furniss, G. J. (2008). Celebrating the artmaking of children with autism. Art Education, 61(5), 812. https://doi.org/10.1080/00043125.2008.11518990 
Gadamer, H.-G. (2013). Truth and method (J. Weinsheimer \& D. G. Marshall, Trans.). Bloomsbury. (Original work published 1975)

Garber, E. (1992). Feminism, aesthetics, and art education. Studies in Art Education, 33(4), 210-225. http://www.jstor.org/stable/1320667

Garrison, J. W. (1995). Style and the art of teaching. In J. W. Garrison \& A. G. Rud, Jr. (Eds.), The educational conversation: Closing the gap (pp. 41-60). State University of New York Press.

Geijsel, F., \& Meijers, F. (2005). Identity learning: The core process of educational change. Educational Studies, 31(4), 419-430. https://doi.org/10.1080/03055690500237488

Gelineau, R. P. (2012). Integrating the arts across the elementary school curriculum (2nd ed.). Wadsworth Cengage.

Glaser, B. G., \& Strauss, A. L. (2012). The discovery of grounded theory: Strategies for qualitative research. Routledge. (Original work published 1967)

Goffman, E. (1959). The presentation of self in everyday life. Doubleday.

Greene, M. (2001). Variations on a blue guitar: The Lincoln Center Institute lectures on aesthetic education. Teachers College Press.

Hall, J. (2010). Making art, teaching art, learning art: Exploring the concept of the artist teacher. International Journal of Art \& Design Education, 29(2), 103-110. https://doi.org/10.1111/j.1476-8070.2010.01636.x

Henri, R. (2007). The art spirit. Basic Books. (Original work published 1923)

Hong, J. Y. (2010). Preservice and beginning teachers' professional identity and its relation to dropping out of the profession. Teaching and Teacher Education, 26(8), 1530-1543. https://doi.org/10.1016/j.tate.2010.06.003

Ingersoll, R. M., \& Strong, M. (2011). The impact of induction and mentoring programs for beginning teachers: A critical review of the research. Review of Educational Research, 81(2), 201233. https://doi.org/10.3102/0034654311403323

Jalongo, M. R., \& Stamp, L. N. (1997). The arts in children's lives: Aesthetic education in early childhood. Allyn and Bacon.

Joseph, A. (2011). Options for implementing the arts standards through visual arts by grade level. Washington State Office of Superintendent of Public Instruction. http://www.k12.wa.us/Arts/Standards/pubdocs/VisualArtsStandards.pdf

Joseph, D., \& Heading, M. (2010). Putting theory into practice: Moving from student identity to teacher identity. Australian Journal of Teacher Education, 35(3), 75-87. https://doi.org/10.14221/ajte.2010v35n3.6

Joseph, P. B., Mikel, E. R., \& Windschitl, M. A. (2011). Reculturing curriculum. In P. B. Joseph (Ed.), Cultures of curriculum (2nd ed., pp. 55-77). Routledge.

Kelley, J. E., Stair, M., \& Price, P. G. (2013). Anthropomorphic veneers in Voices in the Park: Questioning the master narratives through a socio-historical analysis of images and text. The Dragon Lode, 31(2), 4453 .

Lehr, S. (Ed.). (2001). Beauty, brains, and brawn: The construction of gender in children's literature. Heinemann.

Lewis, T. E. (2014). The aesthetics of education: Theatre, curiosity, and politics in the work of Jacques Rancière and Paulo Freire. Bloomsbury. 
Lynch, P. (2007). Making meaning many ways: An exploratory look at integrating the arts with classroom curriculum. Art Education, 6o(4), 33-38. https://doi.org/10.1080/00043125.2007.11651651

Marsh, A. (2004). Pragmatist aesthetics and new visions of the contemporary art museum: The Tate Modern and the Baltic Centre for Contemporary Art. Journal of Aesthetic Education, 38(3), 91106. https://doi.org/10.1353/jae.2004.0027

Negishi, M., \& Elder, A. (2005). [Review of the book Public education and imagination-intellect: I speak from the wound in my mouth, by M. E. Weems]. African American Review, 39(3), 473-475. https://www.jstor.org/stable/40033679

Noddings, N. (2012). Philosophy of education (3rd ed.). Westview Press.

Oreck, B. (2004). The artistic and professional development of teachers: A study of teachers' attitudes toward the use of the arts in teaching. Journal of Teacher Education, 55(1), 5569. https://doi.org/10.1177/0022487103260072

Ornstein, A. C., Levine, D. U., \& Gutek, G. L. (2011). Foundations of education. Wadsworth.

Parsons, M. J. (1990). Aesthetic literacy: The psychological context. Journal of Aesthetic Education, 24(1), 135-146. https://doi.org/10.2307/3332861

Petchauer, E. (2012). Sampling memories: Using hip-hop aesthetics to learn from urban schooling experiences. Educational Studies, 48(2), 137-155. https://doi.org/10.1080/00131946.2011.647148

Poe, P., Fisher, M., Brandon, S., Hutchins, D., \& Goodman, M. (2019). Music of the 1960s: The praxis of ideological change. Journal of Social Change, 11(1), 30-37.

https://doi.org/10.5590/JOSC.2019.11.1.03

Rex, L., \& Woywod, C. (2014). Envisioning home, self, and community through vernacular art environments. Art Education, 67(6), 40-46. https://doi.org/10.1080/00043125.2014.11519297

Robinson, V. M. J., \& Timperley, H. S. (2007). The leadership of the improvement of teaching and learning: Lessons from initiatives with positive outcomes for students. Australian Journal of Education, 51(3), 247-262. https://doi.org/10.1177/000494410705100303

Rud, A. G. (2011). Albert Schweitzer's legacy for education: Reverence for life. Palgrave Macmillan; https://doi.org/10.1057/9780230116238

Rud, A. G., \& Garrison, J. (2010). Reverence and listening in teaching and leading. Teachers College Record, 112(11), 2777-2792.

Sameshima, P., \& Sinner, A. (2009). Awakening to soma heliakon: Encountering teacher-researcher-learning in the twenty-first century. Canadian Journal of Education, 32(2), 271-284.

http://www.jstor.org/stable/canajeducrevucan.32.2.271

Sameshima, P., \& Vandermause, R. (2008). Parallaxic praxis: An artful interdisciplinary collaborative research methodology. In B. Kožuh, R. Kahn, \& A. Kozlowska (Eds.), The practical science of society (pp. 141-145). The College of Education and Human Development \& Slovenian Research Agency.

Schwartz, S. L., \& Copeland, S. M. (2010). Connecting emergent curriculum and standards in the early childhood classroom: Strengthening content and teaching practice. Teachers College Press.

Seifert, L. S. (1992). Experimental aesthetics: Implications for aesthetic education of naive art observers. The Journal of Psychology, 126(1), 73-78. https://doi.org/10.1080/00223980.1992.10543342

Shockley, K. G., Bond, H., \& Rollins, J. (2008). Singing in my own voice: Teachers' journey toward selfknowledge. Journal of Transformative Education, 6(3), 182-200.

https://doi.org/10.1177/1541344608324017 
Smithrim, K., \& Upitis, R. (2005). Learning through the arts: Lessons of engagement. Canadian Journal of Education, 28(1/2), 109-127. http://www.jstor.org/stable/1602156

Stanford Center for Assessment, Learning, and Equity. (2019). Making good choices: Candidate support resource [Handbook]. Board of Trustees of the Leland Stanford Junior University. https://www.edtpa.com/Content/Docs/edTPAMGC.pdf

Thomas, L., \& Beauchamp, C. (2011). Understanding new teachers' professional identities through metaphor. Teaching and Teacher Education, 27(4), 762-769. https://doi.org/10.1016/j.tate.2010.12.007

Weems, M. E. (2003). Public education and imagination-intellect: I speak from the wound in my mouth. Peter Lang.

Whitaker, C. J. (2015). Race-ing the dragon: The Middle Ages, race, and trippin' into the future. Postmedieval: A Journal of Medieval Cultural Studies, 6(1), 3-11. https://doi.org/10.1057/pmed.2014.40

Whitehead, A. N. (1967). The aims of education and other essays. The Free Press. (Original work published 1929)

Wiebe, S., Sameshima, P., Irwin, R., Leggo, C., Gouzouasis, P., \& Grauer, K. (2007). Re-imagining arts integration: Rhizomatic relations of the everyday. The Journal of Educational Thought, 41(3), 263280. https://www.jstor.org/stable/23765522

Yob, I. M. (2018). Conceptual framework for a curriculum in social change. Journal of Social Change, 1O(1), 71-80. https://doi.org/10.5590/JOSC.2018.10.1.06

The Journal of Social Change, sponsored by Walden University, welcomes manuscripts focusing on interdisciplinary research in social change that improves the human condition and moves people, groups, organizations, cultures, and society toward a more positive future. 